\title{
FEATURES OF WEATHER TYPES INVOLVING HEAVY RAINFALL ALONG THE SOUTHERN SPANISH MEDITERRANEAN
}

\author{
JOSÉ MARÍA SENCIALES-GONZÁLEZ ${ }^{*}$, JOSÉ D. RUIZ-SINOGA ${ }^{1}$
}

${ }^{1}$ Department of Geography, Universidad Malaga, Campus de Teatinos, 29071 Málaga, Spain.

\begin{abstract}
Heavy rainfall events in the Mediterranean can be of high intensity, commonly exceeding $100 \mathrm{~mm}$ day $^{-1}$, and have irregular spatio-temporal distribution. Such events can have significant impacts both on soils and human structures. The aim of this paper is to highlight a systematic comparison of synoptic conditions with heavy rainfall events in Mediterranean Southern Spain, assessing the weather types responsible for meteorological risk in specific locations of this mountainous region. To do this, we analyzed the maximum intensity of rainfall in observational periods ranging from $10 \mathrm{~min}$ to $24 \mathrm{~h}$ using a database from 132 rain gauge stations across the study area since 1943; then, the heavy rain has been associated with the weather type which triggers it. This analysis identified a pattern of heavy rainfall which differs from that previously reported in the Mediterranean area. Thus, in this research, the maximum number of heavy rainfall events uses to come from a dominant pattern of low pressures associated to front systems and East-Northeast winds; but the maximum volumes use to be associated to Cold Drops and the same winds; in addition, there are differences throughout the territory, showing several patterns and seasonal incidence when analyzing sub-zones, which may be related with different erosive conditions according to its position with respect to Atlantic or Mediterranean sea, and the entity of its relief.
\end{abstract}

\section{Características de los tipos de tiempo que implican precipitaciones intensas a lo largo de la España sur mediterránea.}

RESUMEN. Los eventos de fuertes precipitaciones en el Mediterráneo pueden ser de intensidad alta (superando habitualmente los $100 \mathrm{~mm} \mathrm{día}^{-1}$ ) y tener una distribución espacio-temporal irregular. Estos eventos también pueden tener impactos significativos en los suelos y en las infraestructuras. El objetivo de este artículo es plantear una comparación sistemática de condiciones sinópticas con eventos de fuertes lluvias en la España sur mediterránea, evaluando los tipos de tiempo responsables del riesgo meteorológico en localizaciones específicas de esta región montañosa. Para lograr este objetivo, se analiza la intensidad máxima de precipitación desde 1943 en un periodo de observación de 10 minutos a 24 horas usando una base de datos de 132 estaciones meteorológicas. Posteriormente, la lluvia intensa se ha asociado con el tipo de clima que la desencadena. Este análisis identificó un patrón de fuertes lluvias que difiere del conocido con anterioridad en el área mediterránea. En consecuencia, en esta investigación, el número máximo de eventos de lluvias intensas suele ocasionarse a partir de bajas presiones asociadas a sistemas de frente y vientos del Este-Noreste, pero los volúmenes máximos suelen estar asociados a Gotas Frías y a los mismos vientos. Además, existen diferencias en todo el territorio, mostrando varios patrones e incidencia estacional al analizar subzonas, que pueden estar relacionadas con diferentes condiciones erosivas según su posición respecto al Atlántico o Mediterráneo y la entidad del relieve.

Key words: Heavy rainfall, Mediterranean, Synoptic Weather Situation, Climate Change.

Palabras clave: precipitaciones intensas, Mediterráneo, Simulación sinóptica del tiempo, cambio climático. 
*Corresponding author: J. M. Senciales-González. Department of Geography, Universidad Malaga, Campus de Teatinos, 29071 Málaga, Spain. E-mail: senciales@uma.es.

\section{Introduction}

Heavy rainfall events in the Mediterranean can be of high intensity and irregular spatio-temporal distribution (Romero et al., 1999; Llasat, 2001; Peñarrocha et al., 2002; Beguería et al., 2009). They commonly involve rainfall exceeding $100 \mathrm{~mm} \mathrm{~h}^{-1}$, and sometimes reach levels exceeding $375 \mathrm{~mm} \mathrm{~h}^{-1}$ (Camarasa, 1994), and it is not unusual for the annual average to be exceeded by factors of two or three in single events (Gil Olcina, 1989).

These events have hydrological, territorial, economic, and social consequences, and detrimentally affect the quality of life of affected communities. From the hydrological point of view the rainfall levels are critical as they affect the rainfall-to-runoff relationship, impacting the initial infiltration capacity of the soil and runoff thresholds and coefficients (Yair and Lavee, 1985; Camarasa and Segura, 2001; Cammeraat, 2004; Rodrigo Comino et al., 2016; Camarasa et al., 2020), and often result in flash floods.

The increased risks associated with heavy rainfall events are not only environmental, but increase the vulnerability of affected communities, particularly under the effects of climate change (IPCC, 2001, 2007, 2014, 2019). Changes in the water cycle, hydrological patterns, and climatic patterns are of great concern to affected populations, and consequently are receiving increased research attention (Guijarro Pastor, 2002; Katz et al., 2005; Negri et al., 2005; De Luis et al., 2010; Coscarelli and Caloiero, 2012; Lemus and López, 2016; Olcina, 2017). These changes affect economic activities (including agriculture, energy production, and drinking water supply) and natural risks (including dry spells, floods, and landslides) (Hennessy and Pittock, 1995; Ferrari et al., 2013; Martínez Navarro, 2018).

This process is an indicator of current climate change, as Mediterranean societies have historically adapted to changes in resources and risks (Butzer, 2005), and have remained resilient to past fluctuations in the magnitude and intensity of extreme weather episodes. However, the current situation may herald major impacts on natural and anthropic aspects of water resources in Mediterranean areas.

The increasing number of days exceeding the long-term average maximum and minimum temperature in Mediterranean environments (Barcena et al., 2018) is causing the energy accumulated in the system to intensify the hydrological cycle, and so increase the number of extreme high intensity rainfall events, which in turn result in a greater number of catastrophic floods (European Environment Agency, 2018a), with their attendant risks.

An important issue is the definition of a heavy rainfall event. These are considered to be characterized by high intensity and having the capacity to generate significant impacts on and changes in affected areas (Martín and Llasat, 2000). However, because of various meanings of the term 'extreme event', diverse definitions of heavy rainfall events have been in use in recent decades (Schumm, 1980; Palmer and Ralsanen, 2002; Trenberth et al., 2015). Among these, the definition of Beniston et al. (2007) includes that for an event to be considered extreme, three main criteria must be met: rarity, intensity, and severity. For the entire Spanish territory an extreme event has been defined by Martín Vide (1989) as one generating rapid, excessive and short-lived surface runoff, involving at least $100 \mathrm{~mm} 24 \mathrm{~h}^{-1}$ (Santos Deltell, 1991; Olcina Cantos, 2000; Senciales and Ruiz, 2013). According to the State 
Meteorological Agency of Spain (AEMET, 2013), this equates to $60 \mathrm{~mm} \mathrm{~h}^{-1}$ or greater. However, variability in rainfall measurement at the national level requires a better definition of heavy rainfall. Hence, Olcina Cantos (2000) identified the need to establish a new rainfall threshold that corresponds to historical severe physical or human consequences.

Knowledge of the amount and intensity of rainfall is important in the Mediterranean area (Alpert et al., 2002; Olcina, 2017); thus, in some cases geomorphological rainfall has been defined as being of very high intensity and short duration, with the ability to modify the land (Sillero et al., 2019). The consequences of increasing rainfall intensity are worse in this environment, where the impacts of human activities have been substantial in recent centuries. The European Environment Agency has confirmed an increase in heavy rainfall in the north and northeast of Europe but has reported diverse trends in the southern Europe (European Environment Agency, 2018b).

The records of rainfall differ according to the time scale used for the observations (Waymire and Gupta, 1981; Valdés et al., 1985; Jebari et al., 2007; Dunkerley, 2008), increasing its intensity and irregularity according to the reduction of the observation time interval. However, Sillero et al. (2019) noted that the most appropriate time interval to measure the intensity of rainfall is not clear, and that it can differ according to the type of phenomenon being investigated, the scale at which it is produced, and the specific objectives of the research. For example, basin-scale processes depend on the occurrence of specific episodes of rainfall (Cammeraat, 2004; Conesa García, 2005), and hydrological connectivity (the continuity of water flow in the basin from the headwaters to the outlet) in the particular morphoclimatic context (Bracken et al., 2013). In humid environments the basal flow and the antecedent humidity are important, while in semi-arid environments the duration and intensity of the rain episodes are major factors, especially when the duration of a rainfall event is greater than the run-off concentration time of the basin or when the intensity of the rainfall is very high (Yair and Kossovosky, 2002; Yair and Raz-Yassif, 2004; Bracken et al., 2008).

According to the Fifth Assessment Report of the Intergovernmental Panel on Climate Change, daily rainfall records are insufficient for studying heavy rainfall in Mediterranean areas (Hartmann et al., 2013), and that more finer time scales are needed (Bengtsson and Milloti, 2010; Monjo, 2016). Empirical studies carried out by Camarasa-Belmonte and Soriano (2014) have shown that many natural processes in Mediterranean environments are related to rainfall intensity on time scales of less than 24 h. This feature is also highlighted by Rodrigo et al. (2019). Consequently, some studies (Bengtsson and Milloti, 2010) have emphasized the importance of information on short-term rainfall for applied problems such as the design of stormwater drainage systems. However, in Spain there was a lack of short-term rainfall data until the creation of an automatic water information system (SAIH), and sometimes the data is of poor quality because of the distribution of measurement stations. This problem is most serious in semiarid areas, where rainfall data is usually recorded daily. Therefore, there is a need to use mathematical models to estimate rainfall intensity at shorter time scales (hours, minutes), based on reprocessing of daily data (Salson-Casado and García-Bartual, 1998; Bacchini and Zannoni, 2003; Egozcue et al., 2006; Rusjan et al., 2009), even though such modeling can overestimate or underestimate some parameters (Bengtsson and Milloti, 2010). However, it is essential to study rainfall intensity at various scales to determine which are the most representative, to identify how the maximum values of each time scale are spatially distributed, and to evaluate which have the main geographical effects.

A second issue stems from the fact that in southern Spain, heavy rainfall phenomena may result from the Mediterranean and Atlantic (across the Strait of Gibraltar) rainfall patterns (east and west patterns, respectively). This duality has been analyzed in general terms in numerous studies (Pons and Soriano, 1994; De Luis et al., 1997; Pascual et al., 2001; Martin Vide, 2004; Llasat et al., 2005; Neppel et al., 2007; Rodrigo and Barriendos, 2008; Lana et al., 2009; Turco and Llasat, 2011; SencialesGonzalez and Ruiz-Sinoga, 2013), along with the episodic atmospheric dynamics that affect these patterns (Martín et al., 2006; Martin Vide et al., 2008; Camarasa et al., 2010, 2018, 2020). 
The systematic comparison of synoptic situations associated with heavy rainfall events enables analysis of the weather conditions increasing meteorological risk in specific locations, as it is evident that topography affects atmospheric circulation (Hartung et al, 2019), especially in areas such as the Mediterranean slope (Santos-Muñoz et al, 2020), where the height of the landforms commonly exceeds $1000 \mathrm{~m}$ over short distances.

Numerous studies have investigated mesoclimatic features affecting the Mediterranean climate. The studies of Elías and Ruiz (1979), Font Tullot (1983), López Gómez (1969, 1983), Albentosa (1991), and Capel Molina (2000) on the general climate of the Iberian peninsula are important, and draw attention to the particularities of some places in the Mediterranean, especially those including the eastern zone, where catastrophic rainfall events reoccur in a phenomenon that has been referred to as "the supposed monsoon of the Iberian Peninsula" (López Gómez, 1969). In the eastern Mediterranean area, the dynamics and trends of convective rainfall episodes have been extensively analyzed (Millan et al., 2005; Estrela et al., 2006), including their association with unusual increases in temperature (Miro et al., 2015). However, the Mesoscala convective systems (Zipser, 1982) depend on different flows in the Alboran Sea (Xoplati et al., 2012; Senciales-González and Ruiz Sinoga, 2013; Ruti et al., 2016).

In this study we analyzed the maximum intensity of rainfall in observation periods ranging from $10 \mathrm{~min}$ to $24 \mathrm{~h}$ in a particularly sensitive area in the southern Iberian Peninsula, and the dominant types of weather which are responsible. The study objectives were to assess the characteristics of heavy rainfall events at various time scales, its seasonal and geographic variability, and the meteorological conditions involved.

\section{Methods and study area}

The major heavy rainfall events recorded in southern Spain were analyzed based on the two main official databases: the Spanish Meteorological Agency (AEMET) database and that of the Alert System and Hydrological Information (SAIH) network of Spain.

First, it is necessary to clarify two concepts: "event" and "case". i) An event is a weather situation, generalized or not, that involves heavy rain. ii) A case is the rainfall data registered by a

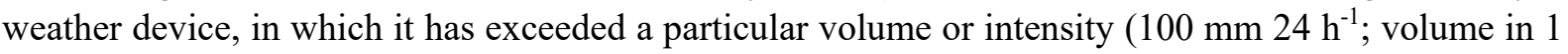
$\mathrm{h}$; volume in $10 \mathrm{~min}$ ).

We analyzed 83 events and 203 cases of rainfall exceeding $100 \mathrm{~mm}$ in $24 \mathrm{~h}, 44$ events and 90 cases of rainfall exceeding $20 \mathrm{~mm} \mathrm{~h}^{-1}$, and 44 events and 90 cases of intense rainfall lasting $<10 \mathrm{~min}$. It has been used data from 132 rain gauge stations since 1943 to 2019.

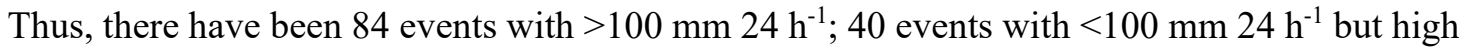
hourly intensity; and 44 events with high intensity in $10 \mathrm{~min}$. Given that some events registered as $>100$

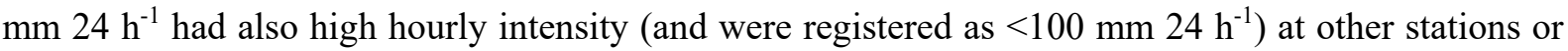
areas, in total we analyzed 114 events (Table 2), because some events are recorded with the three type of intensity. Thus, in these cases, an event is characterized by several cases through the same or different area.

We developed a database recording events, season, and event dates. In addition, rainfall events of 10 min not only recorded maximum intensity during $10 \mathrm{~min}$, but also were contrasted with the total amount of rainfall during the hour and day which did occur.

We identified six zones on the Mediterranean slope in southern Spain, based on their distances from the Atlantic Ocean and their topographical characteristics (Fig. 1).

1. (R) Campo de Gibraltar, the Ronda Mountains and the west coast of Málaga province (from Calaburras Cape to Manilva). 
2. (G) Guadalhorce Valley, the central coast of Malaga province (from Calaburras to Málaga) and the west slope of Montes de Málaga.

3. (A) Axarquía shire.

4. (S) The semiarid zone of the Granada and Almería provinces.

5. (N) Sierra Nevada (Granada-Almería, $>1000$ m height).

6. (D) The sub-desert domain of Almería.

Each event was associated according to four characteristics: i) ground level weather situation, ii) $500 \mathrm{hPa}$ level weather situation, iii) dominant ground-level wind, and, iv) $500 \mathrm{hPa}$ level winds. On this basis, weather types were classified and related to the rainfall volumes and number of cases, and to statistical estimators. Events and cases were distinguished: thus, an event involving heavy rainfall may have been recorded at only one weather station (one event with only one case), or at several stations (one event with several cases).

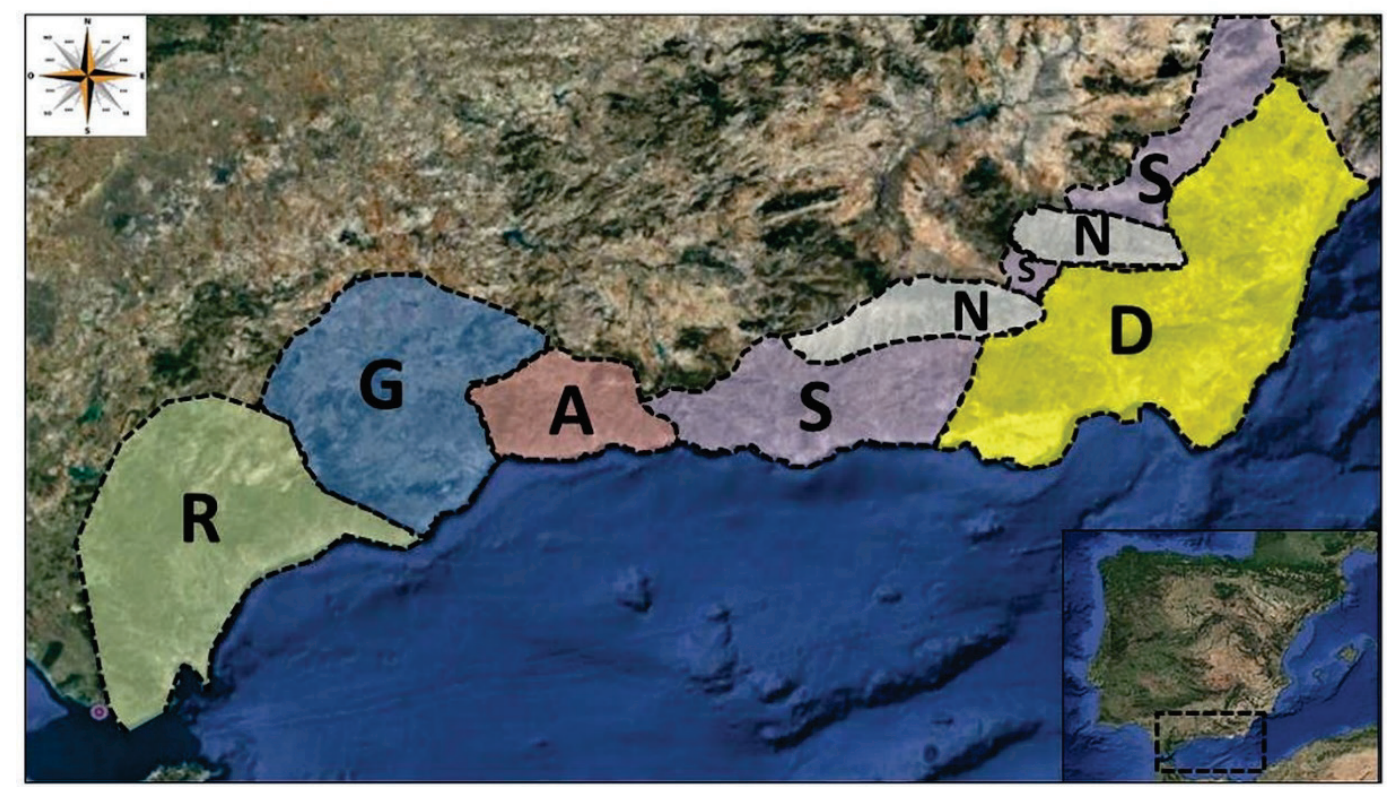

Figure 1. Study area. R: Campo de Gibraltar, Ronda Mountains and West Coast of Málaga province. G: Guadalhorce Valley, central coast of Málaga province and West slope of Montes de Málaga. A: Axarquia shire. S: Semiarid zone of Granada and Almería provinces. N: Sierra Nevada (Granada-Almería, >1000 m). D: Subdesert domain of Almería.

Six weather types were identified (Rodrigo et al., 2020):

1. Dynamic low pressure without fronts (DL): dynamic low-pressure events lacking associated fronts throughout the complete event.

2. Cold air pool (CD): weather systems involving cold-air damming at height, but without low pressure at ground level. Thus, any element with a positive surface pressure $(>1014 \mathrm{hPa})$ linked to an isolated cold air cell at height was classified as a CD.

3. Thermal low pressure (TL): these are rainfall events which occur in summer or close to summer characterized by low pressure at ground level, but height values higher than 5520 $\mathrm{m}$. at $500 \mathrm{hPa}$ levels. They may or may not be associated with frontal systems. 
4. Weak Anticyclones or Weak Low-pressure weather systems (WA-D): It is usual that barometric swamps evolve in a few hours to local thermal low pressure or let the arrival of moisture-laden air from the sea. They involve an undefined field of pressure that is sometimes linked to heavy rainfall; they lack frontal systems.

5. Dynamic low pressure with fronts $(\mathrm{DL}+\mathrm{F})$ : dynamic low-pressure weather systems that show instability in all atmosphere levels. The frontal system determines the precipitation period, and up to three fronts may occur during the same event.

6. High pressure weather systems with fronts $(\mathrm{A}+\mathrm{F})$ : high pressure systems associated with unstable air masses, especially those of maritime origin and in contact with masses having different characteristics (temperature/humidity). In these cases, the high-pressure systems show internally levogyrous curvature coincident with respect to the fronts.

These weather types were analyzed on the basis of four rainfall levels as follows.

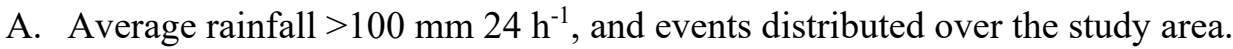

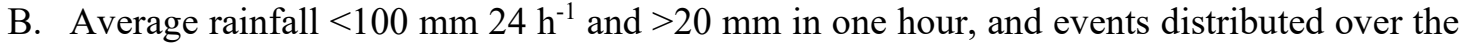
study area.

C. Hourly average rainfall $>20 \mathrm{~mm}$ during events (regardless of the total volume), and events distributed over the study area.

D. Average 10-minute rainfall rate during events $>20 \mathrm{~mm} \mathrm{~h}^{-1}$, and total amount of 10-minutes rainfall compared with total amount of hourly rainfall events (10-minutes rainfall * $100 / 1$ hour rainfall).

The weather types and rainfall were related to the surface wind direction. Based on cause and regional origin, five wind direction groups were identified: NE-E (winds from the Mediterranean basin); SE-S (from Alborán and Africa); SW-W (from the Atlantic Ocean); N-NW (continental winds); and Variable (winds variable during the event) (Fig. 2).
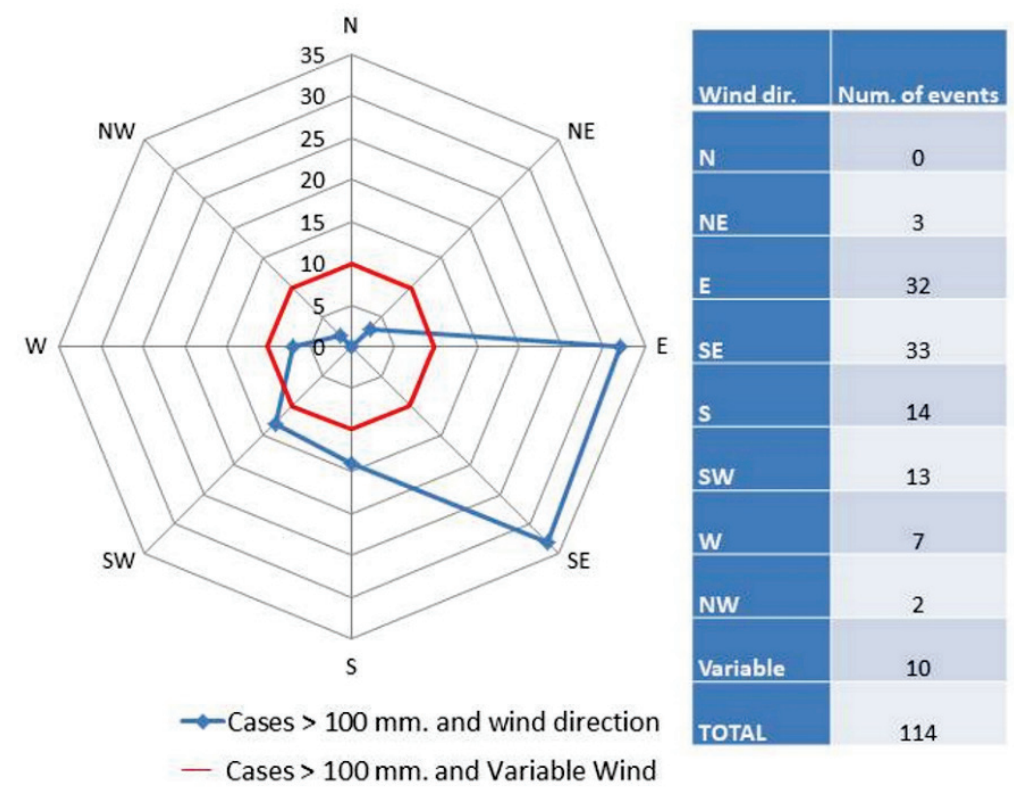

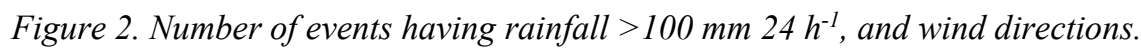




\section{Results}

\subsection{Average rainfall $>100 \mathrm{~mm} 24 \mathrm{~h}^{-1}$, and events distributed over the study area}

More than $50 \%$ of rainfall events $>100 \mathrm{~mm} \mathrm{~h}^{-1}$ affecting the entire study area were associated with the DL $+F$ weather type and NE-E winds, the CD weather type and NE-E winds, and both DL+F and $\mathrm{CD}$ weather types and SE-S winds (Fig. 3).
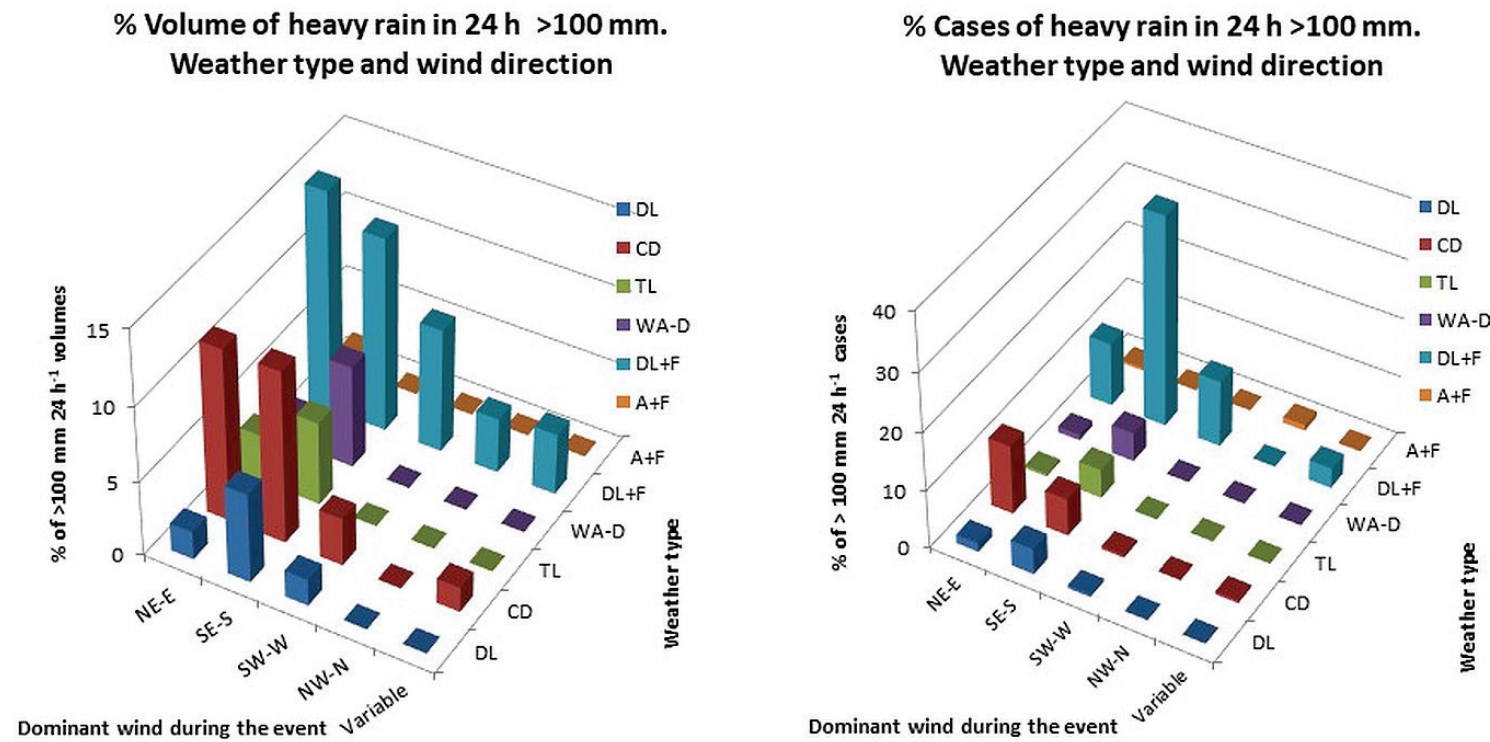

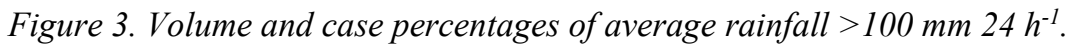

Most frequently events having average rainfall $>100 \mathrm{~mm} 24 \mathrm{~h}-1$ were associated with the DL+F weather type and SE-S winds (36\% of cases), and secondarily with the CD weather type and NE-E winds, the DL+F weather type and NE-E winds, and the DL+F weather type and SW-W winds. These four weather types comprised $70 \%$ of the cases. This indicates that several weather types associated with a few cases involved large precipitation volumes, particularly any weather type associated with SE-S winds, or any wind associated with the DL+F weather type.

There were differences with respect to precipitation volume and the number of cases in each zone.

Maximum rainfall volumes in the semiarid zone of Granada and Almería (hereafter, "the $\mathrm{S}$ zone") were associated with NE-E winds and the DL $+\mathrm{F}$ weather type; but the maximum frequency occurred in the Guadalhorce valley ("the G valley") associated with the CD weather type.

SE-S winds were also associated with maximum rainfall volumes in the $\mathrm{S}$ zone, but in this case associated with the $\mathrm{CD}$ weather type. In contrast, by far the greatest frequency of cases occurred in the Campo de Gibraltar-Ronda mountains (hereafter, "the R mountains").

Maximum rainfall volume in the sub-desert area of Almería (hereafter, "the D area") was associated with SW-S winds and the CD weather type, but this involved only a single case. Apart from this, the maximum average precipitation volume in the $\mathrm{R}$ mountains was associated with the DL+F weather type. With respect to the number of cases, the maximum frequency in the R mountains and the $\mathrm{S}$ zone was associated with the DL+F weather type. 
In only two cases were NW-N winds linked to the $\mathrm{DL}+\mathrm{F}$ weather type, one in the R mountains, and the other in the $\mathrm{S}$ zone.

Variable winds were associated with maximum rainfall values in the $\mathrm{R}$ mountains but involving only a single case associated with the $\mathrm{DL}+\mathrm{F}$ weather type. Apart from this exception, the maximum precipitation average volume occurred in the $\mathrm{D}$ area associated with the DL $+\mathrm{F}$ weather type, the same area that was associated with the maximum case frequency.

\subsection{Average rainfall $<100 \mathrm{~mm} 24 \mathrm{~h}^{-1}$ and $>20 \mathrm{~mm}$ in one hour, and events distributed over the study area}

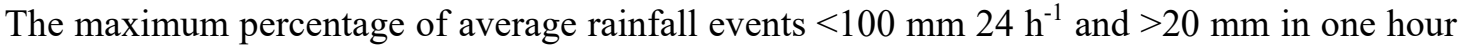
distributed over the study area was associated with the A+F weather type and NE-E winds. A similar percentage were associated with the CD weather type and NE-E winds, and the DL+F weather type associated with SE-S winds. These three weather types accounted for more than $50 \%$ of the rainfall

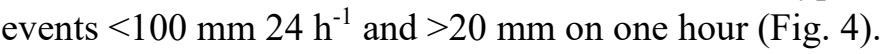

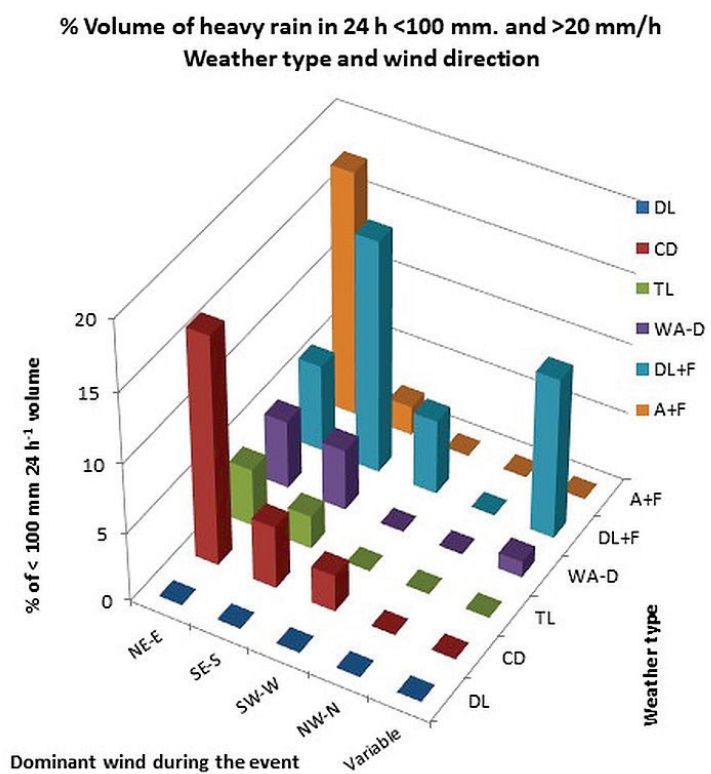

Figure 4. Volume and percentage of cases of rainfall events $<100 \mathrm{~mm} 24 \mathrm{~h}^{-1}$ and $>20 \mathrm{~mm}$ on 1 hour.
$\%$ Cases of heavy rain in $24 \mathrm{~h}<100 \mathrm{~mm}$. and $>20 \mathrm{~mm} / \mathrm{h}$. Weather type and wind direction

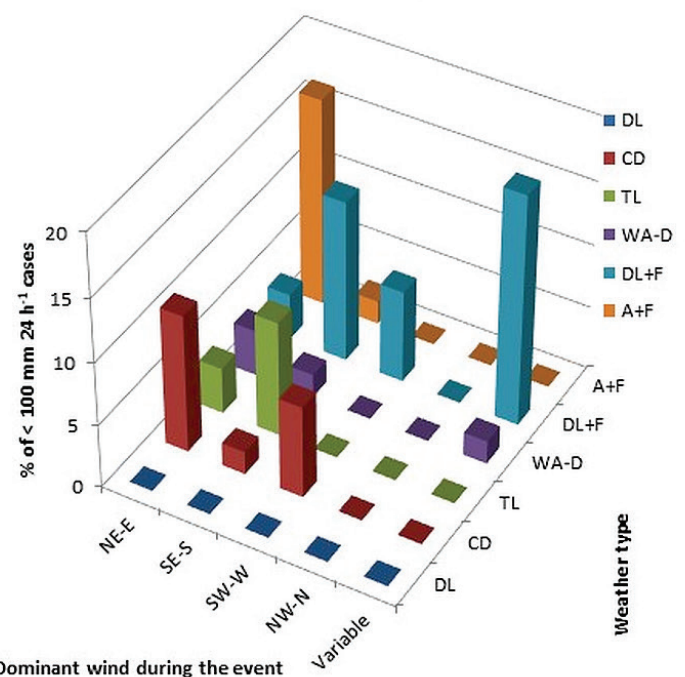

However, the case frequencies differed, with the most frequent rainfall events $<100 \mathrm{~mm}_{2} 4 \mathrm{~h}^{-1}$ and $>20 \mathrm{~mm}$ on one hour being associated with the DL+F weather type and Variable winds $(18 \%$ of cases), and less frequently with the A $+F$ weather type with NE-E winds, the DL+F weather type with SE-S winds, and the CD weather type with NE-E winds. Together, these four weather types comprised $58 \%$ of the cases. This indicates that there were several weather types involving few cases but with high precipitation volumes. For any weather type associated with NE-E winds, or the DL $+F$ weather type associated with SE-S winds, higher rainfall volumes were involved in a few cases of rainfall events $<100$ $\mathrm{mm} 24 \mathrm{~h}^{-1}$ and $>20 \mathrm{~mm}$ in one hour.

There were differences with respect to the volume and number of rainfall cases in each zone. Thus, NE-E winds were associated with maximum rainfall volumes in the $\mathrm{S}$ zone and the $\mathrm{A}+\mathrm{F}$ weather type; but the maximum frequency occurred with the $\mathrm{A}+\mathrm{F}$ weather type in the $\mathrm{D}$ area. 
Maximum rainfall volumes occurred in the G valley associated with the DL+F weather type and SE-S winds. The greatest frequency of cases in the R mountains occurred with several weather types, but intense rainfall was most frequently associated with the $\mathrm{BD}+\mathrm{F}$ weather type with SE-S winds.

Maximum rainfall volumes also occurred in the $G$ valley associated with the $\mathrm{DL}+\mathrm{F}$ weather type and SW-W winds. The highest frequency of cases also occurred in the G valley but associated with the $\mathrm{CD}$ weather type. There were no other cases recorded other than those in the R mountains and the $\mathrm{G}$ valley.

No cases of rainfall of an intensity $>20 \mathrm{~mm} \mathrm{~h}^{-1}$ associated with NW-N winds was recorded, and there were no cases of the DL weather type.

Maximum rainfall occurred with Variable winds in the $\mathrm{R}$ mountains associated with the DL+F weather type, but the highest frequency of cases occurred in the $\mathrm{S}$ zone, also in association with the $\mathrm{DL}+\mathrm{F}$ weather type.

\subsection{Hourly average rainfall $>20 \mathrm{~mm}$ during events (regardless of the total rainfall volume), and events distributed over the study area}

The maximum percentage of rainfall events $>20 \mathrm{~mm} \mathrm{~h}^{-1}$ in the study area were associated with the $\mathrm{CD}$ weather type and NE-N winds, and to a similar but lesser extent with the $\mathrm{A}+\mathrm{F}$ weather type and NE-N winds, the DL $+\mathrm{F}$ weather type and SE-S winds, and the DL $+\mathrm{F}$ weather type and Variable winds. These four weather types accounted for $>56 \%$ of the rainfall events $>20 \mathrm{~mm} \mathrm{~h}^{-1}$ (Fig. 5).

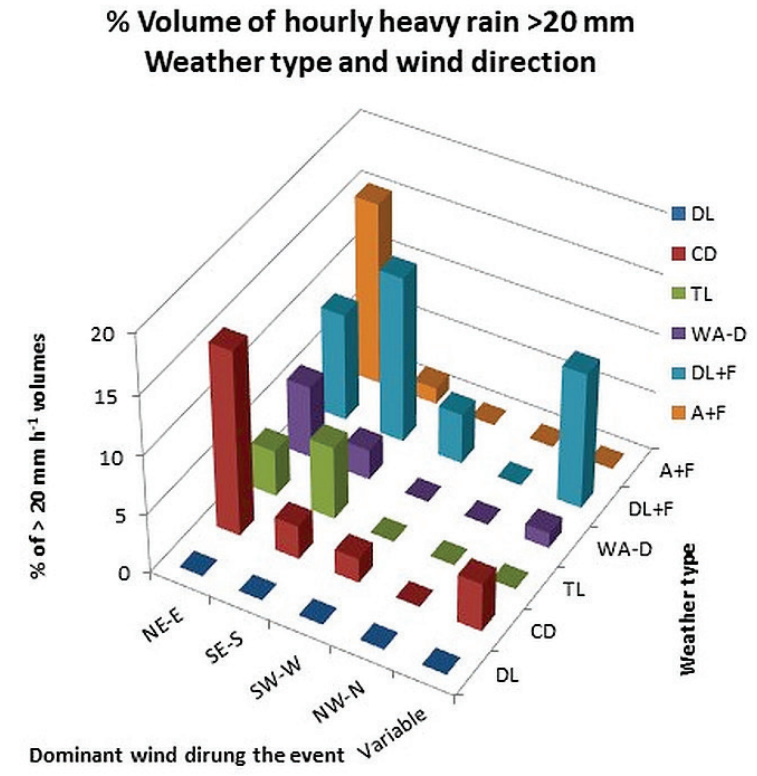

Figure 5. Volume and case percentages for hourly rainfall $>20 \mathrm{~mm}$.
$\%$ Cases of hourly and 10 minutes heavy rain Weather type and wind direction

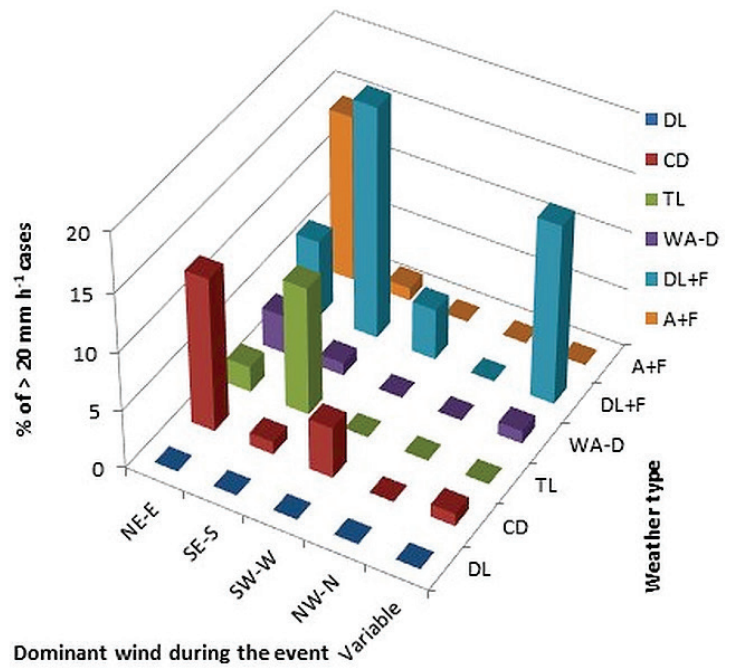

The case frequencies differed only slightly in this analysis. The same weather types were most frequently associated with the cases. Thus, the DL+F weather type with SE-S winds were associated with the highest number of cases, although the DL $+\mathrm{F}$ weather type with Variable winds, the $\mathrm{A}+\mathrm{F}$ weather type with NE-E winds, and the CD weather type with NE-E winds also accounted for a high number of cases. These four weather types accounted for almost $63 \%$ of the cases, with several weather 
types associated with a few cases provided large precipitation volumes. Any weather type associated with NE-E winds accounted for higher volumes for cases involving rainfall $>20 \mathrm{~mm} \mathrm{~h}^{-1}$.

With respect to volume and number of rainfall cases in each zone, the results varied. Thus, NEE winds associated with the DL $+F$ weather type accounted for maximum rainfall volumes $>20 \mathrm{~mm} \mathrm{~h}^{-1}$ in the $\mathrm{S}$ zone, and also the maximum frequency.

SE-S winds associated with TL weather type produced maximum rainfall volumes in the $\mathrm{S}$ zone. As there were $<100 \mathrm{~mm}$ events, the main frequency of cases in the $\mathrm{R}$ mountains was associated with several weather types, with the DL $+F$ type and SE-S winds being the most frequent for $>20 \mathrm{~mm} \mathrm{~h}^{-1}$ events.

SW-W winds showed the same relationship to rainfall events as found for $<100 \mathrm{~mm}$ events, with maximum values associated with the $\mathrm{G}$ valley and the $\mathrm{DL}+\mathrm{F}$ weather type, and the highest frequency of cases occurring in the $G$ valley, but associated with the $C D$ weather type.

When there are variable winds, maximum hourly rainfall values are reached in D area with $\mathrm{DL}+\mathrm{F}$ weather type, but the highest frequency of hourly rainfall cases occurs in the $\mathrm{S}$ zone, also related to the DL+F weather type.

3.4. Average 10-minute rainfall rate during events $>20 \mathrm{~mm} \mathrm{~h}^{-1}$, and total amount of 10-minutes rainfall compared with total amount of hourly rainfall events (10-minutes rainfall * $100 / 1$ hour rainfall).

As the analyzed cases were the same for both hourly and 10-min rainfall, this analysis was centered in the rainfall volumes fallen in ten minutes (Fig. 6).

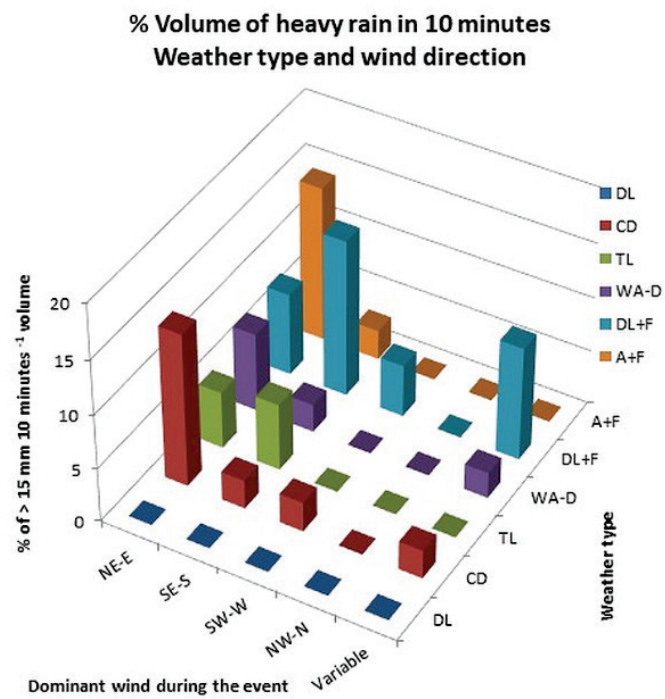

Figure 6. Volume percentages for heavy rainfall in 10 minutes related to rainfall in 1 hour.

The maximum percentage of heavy rainfall during $10 \mathrm{~min}$ in the study area was associated with the $\mathrm{DL}+\mathrm{F}$ weather type and SE-S winds, although similar but lower percentages were associated with the A+F weather type with NE-E winds, and the $\mathrm{CD}$ weather type with NE-E winds. These three weather types accounted for almost $43 \%$ of the 10 -min rainfall events $>20 \mathrm{~mm} \mathrm{~h}-1$. 
Differences with respect to average rainfall volumes in each zone were as follows.

Maximum rainfall volumes in $<10$ minutes were associated with the $\mathrm{CD}$ weather type and NE$\mathrm{E}$ winds in the $\mathrm{R}$ mountains. This shire had the highest intensity, even though the intensity in any area was usually associated with the DL+F weather type.

Maximum volumes in the S zone were associated with the DL+F weather type and SE-S winds. No area clearly showed a maximum rainfall volume, with similar values being found in the G valley, the $\mathrm{D}$ area, and Axarquía shire (A).

SW-W winds showed maximum rainfall values in the $G$ valley associated with the $C D$ weather type.

Variable winds had maximum rainfall values in the D area associated with the DL+F weather type.

\subsection{Summary of rainfall intensities, weather types, and winds by zone}

Table 1 and Figure 7 show the weather types and winds in relation to rainfall volume and cases for each type of intensity analysis and zone. Although there was no clearly defined pattern, some main trends were evident. Thus, the mountainous zones (the R mountains and Sierra Nevada) were dependent on the $\mathrm{CD}$ weather type. The $\mathrm{DL}+\mathrm{F}$ weather type was common both in Axarquía (A) shire and Guadalhorce valley $(\mathrm{G})$, in this case together $\mathrm{CD}$ weather type. The $\mathrm{A}+\mathrm{F}, \mathrm{TL}$, and $\mathrm{CD}$ weather types typically occurred in oriental zones (the $\mathrm{S}$ zone and the $\mathrm{D}$ area). The eastern zone shows similar weather type frequencies to other researches relating rainfall and weather type reported in the East of Spain, including Valencia (Rodrigo et al. 2020). With the exception of Sierra Nevada (N), where NE-E winds and $\mathrm{CD}$ weather type were dominant for any rainfall intensity type, there was no clearly dominant wind direction explaining the rainfall intensity in any zone, although we note that there were no cases involving NW-N or SW-W winds (except in the D area).

The distribution of maximum rainfall values $>100 \mathrm{~mm} 24 \mathrm{~h}-1$ can be generalized as follows. The number of rainfall cases in the western area depended on SE-S winds and the DL+F weather type; on the contrary, the number of rainfall cases in the eastern area depend on NE-E winds combined with the $\mathrm{CD}$ and $\mathrm{DL}+\mathrm{F}$ weather types. The rainfall volume depended on NE-E winds in western and eastern areas, but SE-S winds prevailed in central areas.

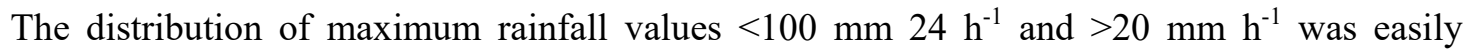
classifiable according to the rainfall volume and wind direction: SE-S winds in western areas, and NE$\mathrm{E}$ winds in eastern areas. The hourly maximum rainfall volumes depended mainly on NE-E or Variable winds. There was no clear association with the frequency of cases. The 10-minute rainfall volume was dependent on NE-E winds in the mountainous areas ( $R$ and $N)$, while the rest of the areas were dependent on SE-S winds. 


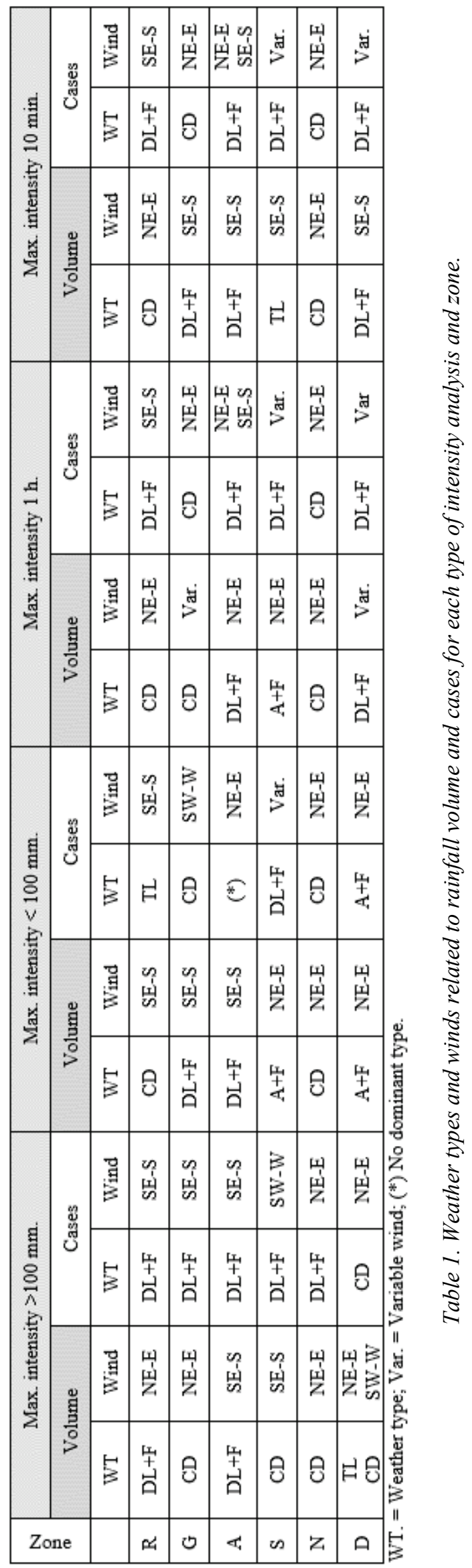




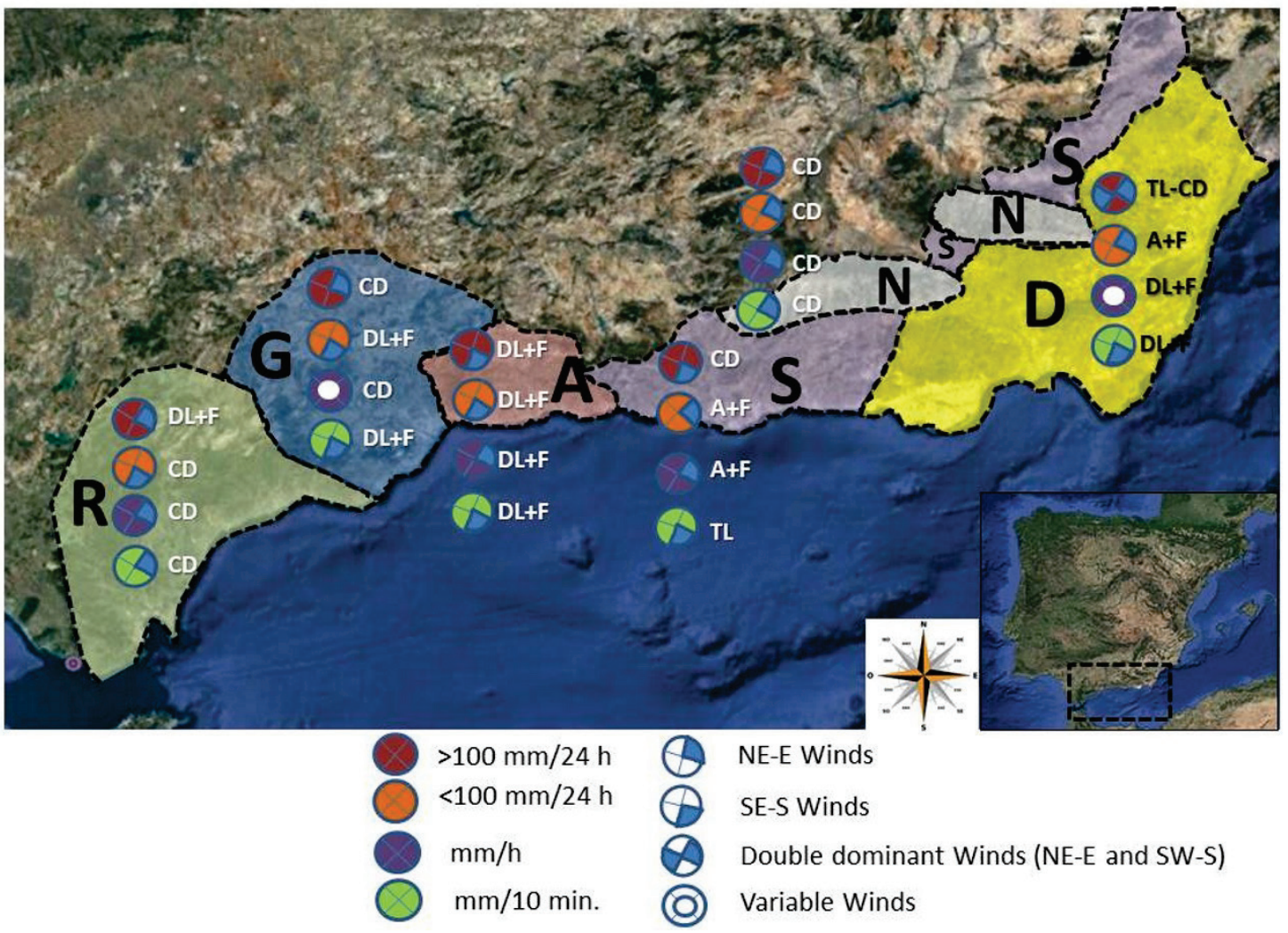

Figure 7. Weather types and wind directions in the study area during maximum intensity events.

\subsection{Summary of events, cases, and volumes related to weather types}

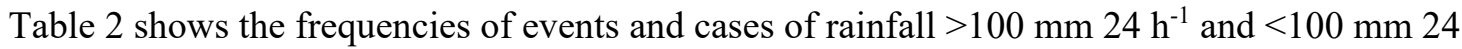
$\mathrm{h}^{-1}$ (but $>20 \mathrm{~mm} \mathrm{~h}^{-1}$ ) related to weather types. This shows that even though the DL+F weather type was associated with a higher frequency of events and cases; the maximum rainfall volume was associated

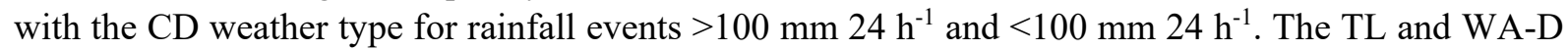

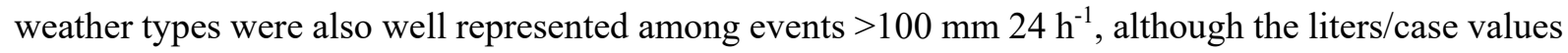
for the TL weather type were lower. The lowest values for events and cases $>100 \mathrm{~mm} 24 \mathrm{~h}^{-1}$ were associated with the $\mathrm{A}+\mathrm{F}$ weather type (only one event and case). There were no cases of events $<100$ $\mathrm{mm} 24 \mathrm{~h}^{-1}$ associated with the DL weather type, and the minimum event and case values were associated with the TL weather type.

Table 2. Events, cases, and volume of rainfall $>100$ and $<100 \mathrm{~mm} 24 \mathrm{~h}^{-1}$.

\begin{tabular}{|c|c|c|c|c|c|c|c|c|}
\hline & $\begin{array}{c}\text { EVENTS } \\
>100\end{array}$ & $\begin{array}{c}\text { CASES } \\
>100\end{array}$ & $\mathrm{~mm} /$ event & Liters/case & $\begin{array}{c}\text { EVENTS* } \\
<100\end{array}$ & $\begin{array}{c}\text { CASES } \\
<100\end{array}$ & $\mathrm{~mm} /$ event & $\mathrm{mm} /$ case \\
\hline $\mathrm{DL}$ & 6 & 13 & 166.58 & 169.21 & 0 & 0 & 0 & 0 \\
\hline $\mathrm{CD}$ & 20 & 39 & 201.03 & 200.58 & 7 & 11 & 62.72 & 58.93 \\
\hline $\mathrm{TL}$ & 4 & 11 & 189.99 & 171.33 & 4 & 7 & 41.37 & 42.53 \\
\hline WA-D & 7 & 12 & 189.93 & 192.88 & 4 & 4 & 48.35 & 48.35 \\
\hline $\mathrm{DL}+\mathrm{F}$ & 46 & 127 & 186.04 & 187.51 & 19 & 23 & 56.56 & 55.90 \\
\hline $\mathrm{A}+\mathrm{F}$ & 1 & 1 & 126.00 & 126.00 & 6 & 10 & 60.76 & 62.63 \\
\hline
\end{tabular}

\footnotetext{
* Because the pluviographic dataset (hourly data) period was shorter (since 1994), there were fewer cases for

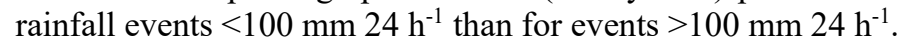


Table 3 shows the frequency of hourly a ten minutes rainfall events and cases. As in Table 2, the maximum hourly rainfall volume was associated with the $\mathrm{CD}$ weather type, but the maximum tenminute rainfall values were associated with the TL weather type.

Table 3. Events, cases, and volume of rainfall $>20 \mathrm{~mm} \mathrm{~h}^{-1}$ and 10 minutes.

\begin{tabular}{|l|cccc|cccc|}
\cline { 2 - 8 } \multicolumn{1}{c|}{} & $\begin{array}{c}\text { EVENTS* } \\
>20 \mathrm{~mm} \mathrm{~h}^{-1}\end{array}$ & $\begin{array}{c}\text { CASES } \\
>20 \mathrm{~mm} \mathrm{~h}^{-1}\end{array}$ & $\begin{array}{c}\mathrm{mm} / \\
\text { event }\end{array}$ & $\begin{array}{c}\text { EVENTS } \\
<10 \mathrm{~min} .\end{array}$ & $\begin{array}{c}\text { CASES } \\
<10 \mathrm{~min} .\end{array}$ & $\begin{array}{c}\text { mm/event } \\
\text { mm/case }\end{array}$ \\
\hline DL & 0 & 0 & 0 & 0 & 0 & 0 & 0 & 0 \\
$\mathrm{CD}$ & 9 & 18 & $\mathbf{4 8 . 5 4}$ & 46.14 & 9 & 18 & 21.28 & 21.36 \\
TL & 5 & 12 & 41.27 & 45.43 & 5 & 12 & $\mathbf{2 2 . 2 3}$ & 23.06 \\
WA-D & 4 & 4 & 30.75 & 30.75 & 4 & 4 & 18.60 & 18.60 \\
DL+F & 20 & 42 & 43.35 & 43.89 & 20 & 42 & 20.49 & 20.74 \\
A+F & 6 & 14 & 43.88 & 46.46 & 6 & 14 & 21.72 & 21.82 \\
\hline
\end{tabular}

* Several events had hourly values $>100 \mathrm{~mm} \mathrm{~h}^{-1}$, so there were more events and cases of rainfall $>20 \mathrm{~mm} \mathrm{~h}^{-1}$ than for $<100 \mathrm{~mm} \mathrm{~h}^{-1}$.

Table 4 shows the weather types and wind directions for ten-minute rainfall values over the study area. This shows (right hand side of Table 4 ) that more than a $50 \%$ of the hourly rainfall occurred in 10 minutes. Moreover, the SW-W wind direction reached the highest average rainfall ratio (rain fall in ten minutes*100/ rainfall in one hour) with a $59.6 \%$ of rainfall amount fallen in only ten minutes. However, the maximum absolute percentage was associated with the A+F weather type and SE-S winds ( $97.7 \%$ of the hourly rainfall fallen in ten minutes).

Table 4. Ten-minute intensity percentage with respect to hourly intensity.

\begin{tabular}{|c|ccccc|ccccc|}
\cline { 2 - 10 } \multicolumn{1}{c|}{} & \multicolumn{1}{c|}{ Average 10-minutes maximum intensity } & \multicolumn{5}{c|}{ \% with respect hourly intensity } \\
\cline { 2 - 11 } & NE-E & SE-S & SW-W & NW-N & Variable & NE-E & SE-S & SW-W & NW-N & Variable \\
\hline DL & 0.00 & 0.00 & 0,00 & 0.00 & 0.00 & 0 & 0 & 0 & 0 & 0 \\
CD & 21.72 & 20.30 & 20.85 & 0.00 & 20.10 & 45.8 & 45.5 & 63.6 & 0 & 31.3 \\
TL & 20.10 & $\mathbf{2 3 . 6 5}$ & 0.00 & 0.00 & 0.00 & 72.7 & 49.8 & 0 & 0 & 0 \\
WA-D & 18.25 & 19.70 & 0.00 & 0.00 & 18.20 & 58.2 & 49.4 & 0 & 0 & 89.7 \\
DL+F & 19.46 & 22.20 & 18.48 & 0.00 & 20.07 & 45.3 & 51.7 & 56.5 & 0 & 47.8 \\
A+F & 21.90 & 20.80 & 0.00 & 0.00 & 0.00 & 47.1 & $\mathbf{9 7 . 7}$ & 0 & 0 & 0 \\
\hline Average & 20.29 & $\mathbf{2 1 . 3 3}$ & 19.66 & 0.00 & 19.46 & 49.0 & 55.1 & $\mathbf{5 9 . 6}$ & 0 & 47.3 \\
\hline
\end{tabular}

\subsection{Seasonal high rainfall by region}

Analysis of heavy rainfall events throughout the study area showed that the highest number of high intensity events $\left(>100 \mathrm{~mm}\right.$ or $>20 \mathrm{~mm} \mathrm{~h}^{-1}$ ) occurred in autumn (62.3\%). However, Table 5 shows that this did not apply in all the study areas, as the high number of cases in autumn skewed the dataset to this season, especially for the $\mathrm{R}$ mountains. Thus, while the $\mathrm{R}$ mountains showed maximum percentages of high rainfall in autumn, in the $\mathrm{G}$ valley it occurred in winter and spring, in Axarquía shire and the D area it occurred in spring, in Sierra Nevada $(\mathrm{N})$ it occurred in winter, and in the $\mathrm{S}$ zone it occurred in summer. The number of cases analyzed in each area ranged from $10(\mathrm{~N})$ to $48(\mathrm{R})$. 
Table 5. Seasonal distribution (\%) of heavy rainfall events in each zone.

\begin{tabular}{lccccccccc} 
& Events & $\%$ & $\mathrm{R}$ & $\mathrm{G}$ & $\mathrm{A}$ & $\mathrm{S}$ & $\mathrm{N}$ & $\mathrm{D}$ \\
\hline Summer & 12 & 10.53 & 16.67 & 11.11 & 11.11 & 33.33 & 5.56 & 22.22 \\
Autumn & 71 & 62.28 & 37.00 & 24.00 & 8.00 & 12.00 & 5.00 & 14.00 \\
Winter & 24 & 21.05 & 25.00 & 25.00 & 7.14 & 14.29 & 14.29 & 14.29 \\
Spring & 7 & 6.14 & 12.50 & 25.00 & 12.50 & 12.50 & 0.00 & 37.50 \\
\hline
\end{tabular}

\section{Discussion}

This study sought to address the inadequacies in Mediterranean areas of daily rainfall records for studying heavy rainfall (Hartmann et al., 2013), and the need for the study of high intensity rainfall at finer time scales (Bengtsson and Milloti, 2010; Monjo, 2016). Thus, we compared the average volume

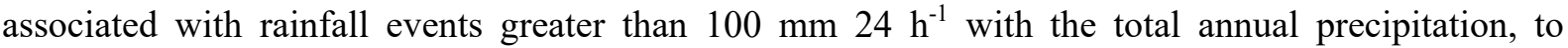
determine the extent to which these events contribute to overall precipitation.

The analysis of rainfall episodes is essential in semiarid environments, because, depending on its intensity (Bull et al., 1999; Hugues, 2005; Yair and Raz-Yassif, 2004; Bracken et al., 2008) and scale (Yair and Raz-Yassif, 2004), an episode can affect resources or may present a risk in many different ways. It is known that in southern of Spain, the torrential nature of the rainfalls can alter the soil water availability for vegetation (Ruiz Sinoga et al., 2019) but also it is able to modify the surficial component of the territory (mass movement, ravine growth, rock falls...) in addition to soil loss; then "geomorphological precipitation" has been proposed as a term which define this type of heavy rain (Sillero et al., 2019).

An important issue for applied research in semiarid environments is to define the most representative rainfall indicator and the best scale for analysis. Because of the variability of the processes, it is necessary to have a series of reference observatories because the number of stations differs among areas. Thus, the $\mathrm{R}$ mountains area has 30 stations, the $\mathrm{G}$ valley has 35 , Axarquía shire has 12, the $\mathrm{S}$ zone has 23, Sierra Nevada has 10, and the D area has 23.

As a result of the high energy and low frequency of these rainfall events in semiarid environments, those of high intensity and short duration have extremely variable spatio-temporal distribution (Romero et al., 1999; Llasat, 2001; Armengot, 2002; Peñarrocha et al., 2002; Beguería et al., 2009). Thus, among the events analyzed for each area, there were only $64.3 \%$ that were isolated, $11.9 \%$ occurred in six or more stations, and 10 events were general and not associated with any particular area. A characteristic of the Spanish Mediterranean area is that although the average annual precipitation is in the range $500-700 \mathrm{~mm}$, a single event can exceed these values by two- or even three-fold (Gil Olcina, 1989). Thus, some events can exceed $800 \mathrm{~mm}$ of precipitation in a single day, as occurred in the city of Gandía in November 1987. In general, in Mediterranean environments it is very common for the rainfall intensity to exceed $100 \mathrm{~mm} \mathrm{~h}^{-1}$ during a storm (Camarasa et al., 2010, 2014, 2020). However, in southern Spain we have no cases in the analyzed series. Of the 100 cases involving hourly precipitation data, 36 exceeded $50 \mathrm{~mm} \mathrm{~h}^{-1}$ and 48 exceeded $20 \mathrm{~mm}$ in $10 \mathrm{~min}$.

The rainfall intensity data are highly valuable in southern Spain, so it is not easy to identify reference thresholds (Montesarchio et al., 2009) because the rainfall characteristics differ according to the observation time scale used (Waymire and Gupta, 1981; Valdés et al., 1985; Jebari et al., 2007; Dunkerley, 2008; Berne et al., 2009). Nevertheless, although there are differences all over the world with respect to the rainfall thresholds, there is a medium confidence about there has been an increase in the intensity of heavy precipitation events at a global scale (IPCC, 2019). It is not clear which is the most appropriate time interval to measure the intensity of the rainfall, although the study of convective cells suggests the use of intensity thresholds of $48-50 \mathrm{~mm} \mathrm{~h}^{-1}$ and an interval of approximately $1 \mathrm{~h}$ between one event and the next (Llasat, 2001). 
The maximum rainfall volume recorded with NE-E winds during rainfall events of $>100 \mathrm{~mm} 24$ $\mathrm{h}^{-1}$ corresponded to a single case of Thermal Low. Apart from this, Dynamic Lows with fronts produced the highest average rainfall volumes, while cold air pools (absent in Axarquía) represented the greatest number of events. Similarly, the highest number of rainfall cases with NE-E winds occur with cold air pools; this weather type shows an average of four cases per area during each event, while it is reduced to 3.67 cases with respect to Dynamic Low with associated fronts; cold air pools accounted for half of the total cases recorded with this wind direction. Although the Guadalhorce valley had most torrential events with this type wind (especially in the form of cold air pools), the highest average rainfall volumes occurred in the semiarid region of Granada, followed by Sierra Nevada $(\mathrm{N})$. The average rainfall volume reached with this wind is $200.45 \mathrm{~mm}$, with an average of 2.58 cases per event and area.

In terms of natural processes and resource and risk management, we identified the appropriate work scales for the specific objectives of this research, given the dynamics of these processes in Mediterranean areas. We determined which scales were the most representative for identifying how the maximum values of each time scale were spatially distributed, and to assess the main geographical influences. To know deeply the heavy rainfall patterns may help to prevent disasters with short-term temporal scale (Seo et al., 2014; Broer and Spira, 2018).

A heavy rainfall pattern was apparent, taking into account the type of weather which it generates; in addition, it differs from that reported for other Mediterranean areas including Catalonia (Martin Vide et al., 2008) and Valencia (Camarasa Belmonte et al., 2010, 2014). Therefore, Facing the purely Mediterranean pattern of these sites in the south of Spain (Alboran Sea) there is a contrast between the Atlantic and subtropical patterns, as previously reported by Peña Angulo et al. (2020). This duality has been analyzed in general terms in numerous studies (Pons and Soriano, 1994; De Luis et al., 1997; Pascual et al., 2001; Martin Vide, 2004; Llasat et al., 2005; Neppel et al., 2007; Rodrigo and Barriendos, 2008; Lana et al., 2009; Turco and Llasat, 2011; Senciales-González and Ruiz-Sinoga, 2013), as has the atmospheric dynamics that is generally involved in such events (Martín et al., 2006; Martin Vide et al., 2008; Camarasa et al., 2010, 2018, 2020; Peña Angulo et al., 2020).

This duality was corroborated as follows: the maximum rainfall volume recorded with SE-S weather was $270 \mathrm{~mm}$, associated with a cold air pool, an event recorded both in the semiarid region of Granada and Almería. Thus, the cold air pools generated a higher average rainfall volume, and the highest average intensity occurred in the Almería semi-desert. However, by far the greatest number of torrential events occurred with dynamic lows in association with fronts; these accounted for more than $50 \%$ of the events with this weather type and more than two-thirds of the cases. Zone A (Campo de Gibraltar, Serranía de Ronda-Marbella) had most cases of this type, with an average of 12.2 cases per event and area. The average volume of torrential rain associated with this type of weather was less than that associated with NE-E winds (183.42 mm.). However, the number of cases associated with NE-E winds was almost double, resulting in almost 5 cases per event and zone, which implies that they are more generalized. Toward the east there was a gradual decrease in the number of cases per area.

\section{Conclusions}

More than $50 \%$ of the heavy rainfall events recorded in Southern Spain were associated with NE-E and SE-S winds. Specifically, the greatest volumes of precipitation $\left(>100 \mathrm{~mm}_{24} \mathrm{~h}^{-1}\right)$ were associated with the DL $+\mathrm{F}$ weather type and NE-E winds, although the greatest number of cases occurs with this weather type and SE-S winds. For hourly intensities (with any rainfall volume in $24 \mathrm{~h}$, this is,

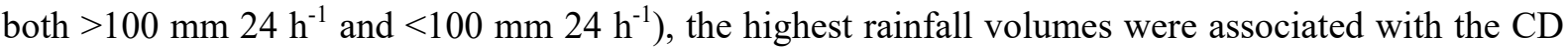
weather type and NE-E winds, and the greatest number of cases was associated with the DL $+F$ weather type and SE-S winds. The 10-minute intensity reaches maximum rainfall volumes of cases with DL+F weather type and NE-E wind, but the highest number of cases is reached with the same weather type, but SE-S winds. Therefore, for high intensity events the incidence of depressions having very active 
fronts should be considered in addition to cold air pools. In addition, different types of weather determined the occurrence of heavy rainfall across the study areas in the southern peninsula. No single weather type or wind direction dominated, except for Axarquía shire (heavy rainfall was always associated with the DL + F weather type) and Sierra Nevada (the CD weather type and NE-E winds were associated with all heavy rainfall events). Moreover, high intensity rainfall events took place at various times of the year. Amongst the study areas, the generalization that heavy rainfall predominantly occurred in autumn only applied to Campo de Gibraltar-Serranía de Ronda. Finally, the intensity of 10-minute rainfall was very high, normally accounting for $50 \%$ of the high intensity rainfall that occurred in one hour, especially associated with the TL and WA-B weather types.

In Alboran sea, in southern Spain a pattern of heavy rainfall was found that differs from that previously reported for the Mediterranean area. This was because of its geographical position, very close to the Atlantic Ocean, and the conjunction of latitude and orography.

\section{Acknowledgments}

The research project CSO2016-75898-P from the Spanish Ministry supported this research. The study was also supported by Campus Andalucía Tech.

\section{References}

Albentosa Sánchez, L. 1991. El clima y las aguas. Col. Geografía de España. Ed. Síntesis. Madrid. 240 pp.

AEMET. 2013. Breve guía descriptiva de los fenómenos meteorológicos recogidos en el Sistema de notificación de observaciones atmosféricas singulares, SINOBAS. In Agencia Estatal de Meteorología (Eds.). Ministerio de Agricultura, Alimentación y Medio Ambiente, Madrid.

Alpert P., Ben-Gai T., Baharad A., Benjamini Y., Diodato L., Ramis C., Homar V., Romero R., Michaelides S., Manes A. 2002. The paradoxical increase of Mediterranean extreme daily rainfall in spite of decrease in total values. Geophys. Res. Lett. 29 (10), 1536. https://doi.org/10.1029/2001GL013554

Bacchini, M., Zannoni, A. 2003. Relations between rainfall and triggering of debrisflow: case study of Cancia (Dolomites, Northeastern Italy). Nat. Hazards Earth Syst. Sci. 3, 71e79

Beguería, S., Vicente-Serrano, S., López-Moreno, J. I., García-Ruíz, J. M., 2009. Annual and seasonal mapping of peak intensity, magnitude and duration of extreme precipitation events across a climatic gradient, northeast Spain. Int. J. Climatol. 29, 1759-1779. https://doi.org/10.1002/joc.1808

Beniston, M., Stephenson, D. B., Christensen, O. B., Ferro, C. A. T., Frei, C. Goyette, S., Woth, K. 2007. Future extreme events in European climate: an exploration of regional climate model projections. Climatic Change 81, 71-95. https://doi.org/10.1007/s10584-006-9226-z

Bengtsson, L., Milloti, S. 2010. Extreme storms in Malmö, Sweden. Hydrol. Process. 24, 3462-3475. https://doi.org/10.1002/hyp.7768.

Blashfield R. K. 1976. Mixture model test of cluster analysis: accuracy of four agglomerative hierarchical methods. Psychol. Bull. 83, 377-388. https://doi.org/10.1037/0033-2909.83.3.377.

Bracken, L. J., Cox, N.J., Shannon, J. 2008. The relationship between rainfall inputs and flood generation in southeast Spain. Hydrol. Process. 22, 683-696. https://doi.org/10.1002/hyp.6641.

Bracken, L.J., Wainwright, J., Ali, G.A., Tetzlaff, D., Smith, M.W., Reaney, S.M., Rou, A.G. 2013. Concepts of hydrological connectivity: research approaches, pathways and future agendas. Earth-Science Reviews. 119, 17-34. https://doi.org/10.1016/j.earscirev.2013.02.001.

Broer, M., Spira, Y. 2018. Scoping study. Existing approaches and methods for heavy rain modelling, mapping and risk assessment. Interreg Central Europe, Rainman. Environment Agency Austria, 48 pp.

Butzer, K.W. 2005. Environmental history in the Mediterranean world: cross-disciplinary investigation of causeand-effect for degradation and soil erosion. J. Archaeol. Sci. 32, 1773-1800. https://doi.org/10.1016/j.jas.2005.06.001. 
Camarasa, A. M. 1994. La intensitat de la precipitació. In: A. Pérez Cueva (Edr.). Atlas climátic de la Comunitat Valenciana, C.O.P.U.T., Valéncia, pp. 100-101.

Camarasa, A. M., Segura, F., 2001. Flood events in Mediterranean ephemeral streams (ramblas) in Valencia region, Spain, Catena 45, 229-249. https://doi.org/10.1016/S0341-8162(01)00146-1.

Camarasa Belmonte, A. M., Soriano García, J., López-García, M. J. 2010. The effect of observation timescales on the characterization of extreme Mediterranean precipitation. Advances in Geoscience 26, 61-64. http://doi.org/10.5194/adgeo-26-61-2010.

Camarasa Belmonte, A. M., Soriano, J., 2014. Empirical study of extreme rainfall intensity in a semi-arid environment at different time scale. J. Arid Environ. 100-101, 63-71. https://doi.org/10.1016/j.jaridenv.2013.10.008.

Camarasa Belmonte, A.M., Caballero López, M.P., Iranzo García, E. 2018. Cambios de uso del suelo, producción de escorrentía y pérdida de suelo. Sinergias y compensaciones en una rambla mediterránea. Bol. As. Geógrafos Españoles 78, 127-153. https://doi.org/10.21138/bage.2714.

Camarasa Belmonte, A., Rubio, M., Salas, J., 2020. Rainfall events and climate change in Mediterranean environments: an alarming shift from resource to risk in Eastern Spain. Natural Hazards. https://doi.org/10.1007/s11069-020-03994-X.

Cammeraat, E. 2004. Scale dependent thresholds in hydrological and erosion response of a semi-arid catchment in southeast Spain. Agr. Ecosyst. Environ. 104, 317-332. https://doi.org/10.1016/j.agee.2004.01.032.

Capel Molina, J.J. 2000. El clima de la Península Ibérica. Ariel Geografía. Barcelona, 281 pp.

Conesa García, C. 2005. Les 'ramblas' du Sud-est Espagnol: systèmes hydromorphologiques en milieu méditerranéen. Z. Geomorphol. 49, 205-224.

Coscarelli, R., Caloiero, T. 2012. Analysis of daily and monthly rainfall concentration in Southern Italy, Calabria region. Journal of Hidrology, 416-417, 145-156. https://doi.org/10.1016/j.jhydrol.2011.11.047.

De Luis, M., González-Hidalgo, J. C., Raventós, J., Sánchez, J. R., Cortina, J. 1997. Distribución espacial de la concentración y agresividad de la lluvia en el territorio de la comunidad Valenciana. Cuaternario y Geomorfologia, 11 (3-4), 33-44.

De Luis, M., Brunetti, M., Gonzalez-Hidalgo, J.C., Longares, L.A., Martin-Vide, J. 2010. Changes in seasonal precipitation in the Iberian Peninsula during 1946-2005. Glob. Planet Change 74, 27-33. https://doi.org/10.1016/j.gloplacha.2010.06.006.

Elías Castillo, F., Ruiz Beltrán, F. 1979. Precipitaciones máximas en España. Ministerio Agricultura. Madrid. 545 pp.

Dunkerley, D. 2008. Identifying individual rain events from pluviograph records: a review with analysis of data from an Australian dryland site. Hydrol. Process. 22, 5024-5036. https://doi.org/10.1002/hyp.7122.

Egozcue, J.J., Pawlowsky-Glahn, V., Ortego, M.I., Tolosana-Delgado, R. 2006. The effect of scale in daily precipitation hazard assessment. Nat. Hazards Earth Syst. Sci. 6, 459-470.

Estrela M.J., Miró, J.J., Millán, M. 2006. Análisis de la tendencia de la precipitación por situaciones convectivas de la Comunidad Valenciana (1959-2004). Clima Soc Medio Ambiente Pub AEC Ser A 5, 125-136.

European Environment Agency. 2018. River floods, climate change adaptation. Water and Marine Environments. https://www.eea.europa.eu/data-and-maps/indicators/river-floods-3/assessment. Accessed 10 Jun 2019.

European Environment Agency (2018b). Heavy precipitation, climate change adaptation. Water and Marine Environments. https:/www.eea.europa.eu/data-and-maps/indicators/precipitation-extremes-in-europe3/assessment. Accessed 10 Jun 2019.

Ferrari, E., Caloiero T., Coscarelli, R. 2013. Influence of the North Atlantic Oscillation on winter rainfall in Calabria (southern Italy). Theoretical and Applied Climatology 114, 479-494. http://dx.doi.org/10.1007/s00704-013-0856-6 .

Font Tullot, I. 1983. Climatología de España y Portugal. Instituto Nacional de Meteorología, Madrid.

Gil Olcina, A. 1989. Causas climáticas de las riadas. Avenidas fluviales e inundaciones en la cuenca del mediterráneo. Instituto Universitario de Geografía de la Universidad de Alicante y Caja de Ahorros del Mediterráneo, 15-30, 1989. 
Guijarro Pastor, J.A. 2002. Tendencias de la precipitación en el litoral mediterráneo español. In: J. A. Guijarro, M. Grimalt, M. Laita, S. Alonso (Eds.), El Agua y el Clima, AEC, Serie A, 3, pp. 427-436, Palma de Mallorca.

Hartmann, D.L., Klein Tank, A.M.G., Rusticucci, M., Alexander, L.V., Brönnimann, S., Charabi, Y.A.R., Dentener, F.J., Dlugokencky, E.J., Easterling, D.R., Kaplan, A., Soden, B.J., Thorne, P.W., Wild, M., Zhai, P. 2013, Observations: Atmosphere and surface. In Climate Change 2013 the Physical Science Basis: Working Group I Contribution to the Fifth Assessment Report of the Intergovernmental Panel on Climate Change. vol. 9781107057999, Cambridge University Press, pp. 159-254. https://doi.org/10.1017/CBO9781107415324.008.

Hartung, K., Shepherd, T.G., Hoskins, B.J., Methven, J., Svensson, G. 2019. Diagnosing topographic forcing in an atmospheric dataset: the case of the North American Cordillera. Quaterly Journal of the Royal Meteorological Society 146, 726. https://doi.org/10.1002/qj.3677 .

Hennessey, K. J., Pittock, A. B. 1995. Greenhouse warming and threshold temperature events in Victoria, Australia. International Journal of Climatology 15, 591-612. http://dx.doi.org/10.1002/joc.3370150602 .

IPCC. 2001. Climate change 2001: the scientific basis. In J. T. Houghton, Y., Ding, D. J. Griggs, M., Noguer, P. J., van der Linden, X. Dai, K. Maskell, C. A. Johnson (Eds.), Contribution of working group I to third assessment report of the intergovernmental panel on climate change, Cambridge University Press. pp. 881, United Kingdom and New York, NY, USA: .

IPCC. 2007. Climate change 2007: the physical science basis. In: S. Solomon, D. Qin, M. Manning, Z. Chen, M. Marquis, K.B. Averyt, M. Tignor, H.L. Miller (Eds.), Contribution of Working Group I to the fourth assessment report of the intergovernmental panel on climate change. Cambridge University Press, Cambridge.

IPCC. 2014. Fifth Assessment Report. IPCC. Retrieved from http://ipcc.ch/report/ar5/.

IPCC. 2019. Climate Change and Land. An IPCC Special Report on climate change, desertification, land degradation, sustainable land management, food security, and greenhouse gas fluxes in terrestrial ecosystems. Summary for policymakers. WMO-UNEP, 41 pp.

Jebari, S., Berndtsson, R., Uvo, C., Bahri, A. 2007. Regionalizing fine time-scale rainfall affected by topography in semi-arid Tunisia. Hydrol. Sci. J. 52, 1199e1215. https://doi.org/10.1623/hysj.52.6.1199.

Katz, R., Brush, G., Parlange, M. 2005. Statistics of extremes: Modeling ecological distur- bances. Ecology 86, 1124-1134. https://doi.org/10.1890/04-0606 .

Lana, X., Burgueño, A., Martínez, M.D., Serra, C. 2009. Una revisión de los análisis estadísticos de las precipitaciones diarias y mensuales en Cataluña. Tethys 6, 15-30.

Lemus Canovas, M., López Bustins, J. 2016. Variabilidad espacio-temporal de la precipitación en el sur de Cataluña y su relación con la oscilación del mediterráneo occidental (WEMO). In Actas del X Congreso Internacional AEC: Clima, sociedad, riesgos y ordenación del territorio. Alicante, October, 5-8. http://doi.org/10.14198/XCongresoAECAlicante2016-21 .

Llasat, M. C. 2001. An objective classification of rainfall events on the basis of their convective features: application to rainfall intensity in the northeast of Spain. Int. J. Climatol. 21, 1385-1400. https://doi.org/10.1002/joc.692.

Llasat, M.C., Barriendos, M., Barrera, A., Rigo, T. 2005. Floods in Catalonia (NE Spain) since the 14th century. Climatological and meteorological aspects from historical documentary sources and old instrumental records. Journal of Hydrology 313, 32-47. https://doi.org/10.1016/j.jhydrol.2005.02.004.

López Gómez, A. 1969. El supuesto monzón de la Península Ibérica. En: Aportación española al XXI Congreso Geográfico Internacional. Instituto Geográfico y Catastral. Madrid. pp. 72-88.

López Gómez, A. 1983. Las lluvias catastróficas mediterráneas. Estudios Geográficos 44, 170/171, 11-29.

Martín Vide, J. 1989. Precipitaciones torrenciales en España. Revista geográfica. Norba 6-7, 63-70.

Martín Vide, J., Llasat, M. C. 2000. Las precipitaciones torrenciales en Cataluña. Serie Geográfica 9, 17-26.

Martín Vide, J. 2004. Spatial distribution of a daily precipitation concentration index in Peninsular Spain. International Journal of Climatology 24, 959-971. https://doi.org/10.1002/joc.1030. 
Martín Vide, J., Sánchez-Lorenzo, A., López Bustins, J. A., Cordobilla, M. J., García Manuel, A., Raso, J. M. 2008. Torrential rainfall in northeast of the Iberian Peninsula: synoptic patterns and WeMO influence. Advances in Science and Research 2, 99-105. http://doi.org/10.5194/asr-2-99-2008.

Martín, M.L., Santos-Muñoz, D., Morata, A, Luna, M.Y., Valero, F. 2006. An objectively selected case study of a heavy rain event in the Mediterranean Basin: A diagnosis using numerical simulation. Atmospheric Research 81, 187-205. https://doi.org/10.1016/j.atmosres.2005.12.002.

Martínez Navarro, J. M. 2018. Gestión territorial del riesgo antrópico de ignición forestal en Castilla-La Mancha. Resumen de la tesis doctoral. Boletín de la Asociación de Geógrafos Españoles 76, 571-576.

Millán, M., Estrela, M. J., Miró, J. J. 2005. Rainfall components: variability and spatial distribution in a Mediterranean área (Valencia Region). J. Clim. 18 (14), 2682-2705. https://doi.org/10.1175/JCLI3426.1.

Miró, J. J., Estrela, M. J., Olcina, J. (2015). Statistical downscaling and attribution of air temperature change patterns in the Valencia Region (1948-2011). Atmos. Res. 156, 189-212. https://doi.org/10.1016/j.atmosres.2015.01.003.

Monjo, R. 2016. Measure of rainfall time structure using the dimensionless n-index. Clim. Res. 67, 71-86. https://doi.org/10.3354/cr01359.

Negri, D.H., Gollehon, N.R., Aillery, M.P. 2005. The effects of climatic variability on US irrigation adoption. Climatic Change 69, 299-323. https://doi.org/10.1007/s10584-005-1817-6 .

Neppel, L., Arnaud, P., Lavabre, J. 2007. Connaissance régionale des pluies extrêmes. Comparaison de deux approches appliquées en milieu méditerranéen. C.R. Geosciences 339, 820-830.

Olcina Cantos, J. 2017. Incremento de episodios de inundación por lluvias de intensidad horaria en el sector central del litoral mediterráneo español: análisis de tendencias en Alicante. Sémata. Ciencias Sociais e Humanidades 29, 143-163.

Olcina Cantos, J., Rico Amorós, A. M. 2000. Estudios sobre lluvias torrenciales e inundaciones en la provincia de Alicante (1982-1999). Serie Geográfica 9, 71-93.

Palmer, T.N., Ralsanen, J. 2002. Quantifying the risk of extreme seasonal precipitation events in a changing climate. Nature 415 (31), 512-514. https://doi.org/10.1038/415512a .

Pascual Aguilar, J.A., Año Vidal, C., Sánchez Díaz, J., Masiá Mira, F. J., Arnau Rosalén, E. (2001). Valoración de la idoneidad de los índices PCI y MFI para estimar la concentración y agresividad de las precipitaciones en la Comunidad Valenciana. Cuaternario y Geomorfología 15 (3-4), 77-88.

Peña-Angulo, D., Nadal-Romero, E., González-Hidalgo, J. C., Albaladejo, J., Andreu, V., Barhi, H., Bernal, S., Biddoccu, M., Bienes, R., Campo, J., Campo-Bescó, M.A., Canatário-Duarte, A., Cantón, S., Casali, J., Castillo, V., Cavallo, E., Cerdà, A., Cid, P., Cortesi, N., Desir, G., Díaz-Pereira, E., Espigares, T., Estrany, J., Farguell, J., Fernández-Raga, M., Ferreira, C.S., Ferro, V., Gallart, F., Giménez, R., Gimeno, E., Gómez, J.A., Gómez-Gutiérrez, A., Gómez-Macpherson, A., González-Pelayo, O., Kairis, O., Karatzas, G.P., Keesstra, S., Klotz, S., Kosmas, C., Lana-Renault, N., Lasanta, T., Latron, J., Lázaro, R., Le Bissonnais, Y., Le Bouteiller, C., Licciardello, F., López-Tarazón, J.A., Lucía, A., Marín-Moreno, V.M., Marín, C., Marqués, M.J., Martínez-Fernández, J., Martínez-Mena, M., Mateos, L., Mathys, N., MerinoMartín, L., Moreno-de las Heras, M., Moustakas, N., Nicolau, J.M., Pampalone, V., Raclot, D., Rodríguez-Blanco, M.L., Rodrigo-Comino, J., Romero-Díaz, A., Ruiz-Sinoga, J.D., Rubio, J.L., Schnabel, S., Senciales-González, J.M., Solé -Benet, A., Taguas, E.V., Taboada-Castro, M.T., TaboadaCastro, M.M., Todisco, F., Úbeda, X., Varouchakis, E.A., Wittenberg, L., Zabaleta, A., Zorn, M. 2020. Relationship of Weather Types on the Seasonal and Spatial Variability of Rainfall, Runoff, and Sediment Yield in the Western Mediterranean Basin. Atmosphere 11, 609. https://doi.org/10.3390/atmos11060609.

Peñarrocha, D., Estrela, M. J., Millán, M. 2002. Classification of daily rainfall patterns in a Mediterranean area with extreme intensity levels: the Valencia region. Int. J. Climatol, 22, 677-695. https://doi.org/10.1002/joc.747.

Pons Marti, V., Soriano Soto, M. D. 1994. Valores de torrencialidad R. Su cálculo y distribución en la provincia de Alicante. Cuadernos de Geografia 56, 163-174.

Rodrigo, F. S., Barriendos, M. 2008. Reconstruction of seasonal and annual rainfall variability in the Iberian Peninsula (16th-20th centuries) from documentary data. Global and Planetary Change 63, 243-257. https://doi.org/10.1016/j.gloplacha.2007.09.004. 
Rodrigo Comino, J., Iserloh, T., Lassu, T., Cerdà, A., Keestra, S. D., Prosdocimi, M., Brings, C., Marzen, M., Ramos, M. C., Senciales, J. M., Ruiz Sinoga, J. D., Seeger, M., Ries, J. B. 2016. Quantitative comparison of initial soil erosion processes and runoff generation in Spanish and German vineyards. Science of The Total Environment 565, 1165-1174. https://doi.org/10.1016/j.scitotenv.2016.05.163.

Rodrigo-Comino, J., Senciales, J. M., Sillero-Medina, J. A., Gyasi-Agyei, Y., Ruiz-Sinoga, J. D., Ries, J. B. 2019. Analysis of Weather-Type-Induced Soil Erosion in Cultivated and Poorly Managed Abandoned Sloping Vineyards in the Axarquía Region (Málaga, Spain). Air, Soil and Water Research 12, 1-11. https://doi.org/10.1177/1178622119839403.

Rodrigo-Comino, J., Senciales-González, J. M., Terol, E., Mora-Navarro, G., Gyasi-Agyei, Y., Cerdà, A. 2020. Impacts of Weather Types on Soil Erosion Rates in Vineyards at "Celler Del Roure" Experimental Research in Eastern Spain. Atmosphere 11 (6), 551. https://doi.org/10.3390/atmos11060551.

Romero, R., Ramis, C., Guijarro, J. A. 1999. Daily rainfall patterns in the Spanish Mediterranean area: an objective classification. Int. J. Climatol. 19, 95-112. https://doi.org/10.1002/(SICI)10970088(199901)19:1<95::AID-JOC344>3.0.CO;2-S.

Rusjan, S., Kobold, M., Mikos, M. 2009. Characteristics of the extreme rainfall event and consequent flash floods in W Slovenia in September 2007. Nat. Hazards Earth Syst. Sci. 9, 947e956.

Ruiz Sinoga, J.D., Hueso González, P., Sillero Medina, J.A., Romero Díaz, M.A. 2019. Impact on soil degradation factors of changes in rain intensity patterns in southern Spain. Ecodesert Symposium, section 1: effects of abiotic factors on ecosystems. 20-22 Feb. 2019.

Ruti, P.M., Somot, S., Giorgi, F., Dubois, C., Flaounas, E., Obermann, A., Dell'Aquila, A., Pisacane, G., Harzallah, A., Lombardi, E., Ahrens, B., Akhtar, N., Alias, A., Arsouze, T., Aznar, R., Bastin, S., Bartholy, J., Béranger, K., Beuvier, J., Bouffies-Cloché, S., Brauch, J., Cabos, W., Calmanti, S., Calvet, J., Carillo, A., Conte, D., Coppola, E., Djurdjevic, V., Drobinski, P., Elizalde-Arellano, A., Gaertner, M., Galàn, P., Gallardo, C., Gualdi, S., Goncalves, M., Jorba, O., Jordà, G., L’Heveder, B., Lebeaupin-Brossier, C., Li, L., Liguori, G., Lionello, P., Maciàs, D., Nabat, P., Önol, B., Raikovic, B., Ramage, K., Sevault, F., Sannino, G., Struglia, M.V., Sanna, A., Torma, C., Vervatis, V. 2016. Med-CORDEX initiative for Mediterranean climate studies. Bull. Am. Meteorol. Soc. 97, 1187-1208. https://doi.org/10.1175/BAMSD14-00176.1.

Salson-Casado, S., García-Bartual, R. 1998. Desagregación de lluvias para aplicaciones en simulación de sistemas de recursos hidráulicos. Rev. Obras Públicas 78, $25 \mathrm{e} 35$.

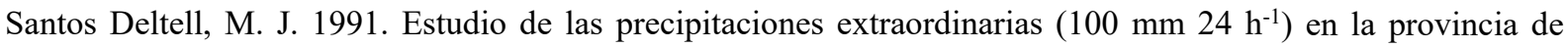
Alicante, 1914-1989. En: Sociedad y Territorio XII Congreso Nacional de Geografía. Universidad de Valencia y Asociación de Geógrafos Españoles, pp. 205-214, Valencia.

Santos Muñoz, D., Morata, A, Martín, M. L., Valero, F. 2006. Simulación numérica de un episodio de precipitación intensa en el Mediterráneo Occidental. Actas de la Asociación Meteorológica Española 29, 1-7.

Schumm, S.A. 1980. Some applications of the concept of geomorphic thresholds. In D. A. Coates, J. D. Vitek (Eds.). Thresholds in Geomorphology. Allen \& Unwin, pp. 472-485, London.

Senciales González, J. M., Ruiz Sinoga, J. D. 2013. Análisis espacio-temporal de las lluvias torrenciales en la ciudad de Málaga. Boletín de la Asociación de Geógrafos Españoles 61, 7-24. http://dx.doi.org/10.21138/bage.1533.

Seo, J.H., Lee, Y.H, Kim, Y-H. 2014. Feature Selection for very short-term heavy rainfall prediction using evolutionary computation. Advances in Meteorology, Article ID 2035452014. https://doi.org/10.1155/2014/203545.

Sillero-Medina, J. A., Hueso-González, P., Ruiz-Sinoga, J. D. 2019. La precipitación geomorfológica como elemento clave en el modelado del paisaje mediterráneo. Boletín de la Asociación de Geógrafos Españoles 82, 1-40. https://doi.org/10.21138/bage.2780.

Turco, M., Llasat, M.C., 2011. Trends in indices of daily precipitation extremes in Catalonia (NE Spain), 19512003. Natural Hazards and Earth System Sciences 11, 3213-3226. http://doi.org/10.5194/nhess-11-32132011.

Trenberth, K. E., Fasullo, J. T., Shepherd, T. G. 2015. Attribution of climate extreme events. Nature Climate Change 5, 725-730. https://doi.org/10.1038/nclimate2657. 
Valdés, J.B., Rodríguez-Iturbe, I., Gupta, V.K. 1985. Approximations of temporal rainfall from a multidimensional model. Water Resour. Res. 21 (8), 1259-1270. https://doi.org/10.1029/WR021i008p01259.

Waymire, E., Gupta, V.K. 1981. The mathematical structure of rainfall representations 1. A review of the stochastic rainfall models. Water Resour. Res. 17 (5), 1261-1272. https://doi.org/10.1029/WR017i005p01261.

Xoplaki, E., Trigo, R.M., García-Herrera, R., Barriopedro, D., D’Andrea, F., Fischer, E.M., Gimeno, L., Gouveia, C., Hernández, E., Kuglitsch, F.G., Mariotti, A., Nieto, R., Pinto, J.G., Pozo-Vázquez, D., Saaroni, H., Toreti, A., Trigo, I.F., Vicente-Serrano, S.M., Yiou, P., Ziv, B. 2012. 6-Large-scale atmospheric circulation driving extreme climate events in the Mediterranean and its related impacts. In: P. Lionello (Edr). The climate of the Mediterranean region. Elsevier, pp. 347-417. https://doi.org/10.1016/B978-012-416042-2.00006-9.

Yair, A., Lavee, H. 1985. Runoff generation in arid and semi-arid zones. MG. Anderson and T.P. Burt (Edrs.). Hydrological Forecasting, 1, 183-220.

Yair, A., Kossovosky, A., 2002. Climate and surface properties: hydrological response of small arid and semi-arid watersheds. Geomorphology 42, 43-57. https://doi.org/10.1016/S0169-555X(01)00072-1.

Zipser, E. J. 1982. Use of a conceptual model of the life-cycle of mesoscales convective systems to improve veryshort range forecasts. In: K. Browning (Edr.), Nowcasting. Academic Press, 191-204, New York. 